Bangladesh J. Bot. 42(2): 367-369, 2013 (December)

\title{
BIOCHEMICAL COMPOSITION OF ENICOSTEMMA LITTORALE BLUME EXTRACTS
}

\author{
P Abirami And M Gomathinayagam* \\ Department of Botany, Faculty of Science, Annamalai University, \\ Annamalainagar, Tamilnadu, India
}

Key words: Enicostemma littorale, Biochemical compounds, Antibacterial activity

\begin{abstract}
Analysis of organic solvent extracts of Enicostemma littorale reveals the presence of total phenols, vitamin $\mathrm{C}$ and $\mathrm{E}$ and carbohydrates. The organic solvent extracts of E. littorale exhibited antibacterial activities.
\end{abstract}

Enicostemma littorale Blume is a perennial glabrous medicinal herb. It is distributed in India and in tropical Africa, Southeast Asia and Malaysia (Ali et al. 2008). The plant has a number of antioxidant phytochemicals including alkaloids, catechins, saponins, sterols, triterpinoids, phenolic acid flavonoids and xanthones. The plant is used in folk medicine to treat diabetes mellitus, rheumatism, ulcers, cancer and inflammation (Murali et al. 2002). This paper deals with the quantitative determination of phytoconstituents and the antimicrobial activity of E. littorale.

Fresh E. littorale plant samples were collected from Erode district, Tamilnadu, India at the end of the flowering season. The plant materials were separated into root, stem and leaf and air dried in a shade at room temperature. The samples were ground to a fine powder. From it $100 \mathrm{~g}$ samples was extracted with chloroform, methanol and acetone by using a soxhlet apparatus. The organic solvent was removed by evaporation using rota evaporator. The residue was then placed in an oven at $40^{\circ} \mathrm{C}$ for about $48 \mathrm{~h}$ to remove the residual water. The resulting dried mass was then powdered, packed into a glass vial and stored in a desiccator. These extracts were used for phytochemical and antibacterial screening. The separated parts into leaves, flowers, stems and roots were cut into small pieces and then used for estimation of protein, carbohydrate and vitamins.

Total phenolic content was estimated after Malick and Singh (1980) and vitamin E after Backer et al. (1980). Vitamin C was extracted and estimated following Omaye et al. (1979). The total protein content was determined after Bradford (1976) and the total carbohydrate content was determined following Dubois et al. (1974).

The bacterial cultures used in this study were obtained from the Department of Medical Microbiology, Raja Muthiah Medical College, Annamalai University, India. The culture consists of three from each of Gram-positive and Gram-negative strains (Table 1). Antibacterial activity of each extract of the plant samples $(500 \mathrm{mg} / \mathrm{ml})$ were evaluated by the paper disc diffusion method (Brantner and Grein 1994). Stock culture of test bacteria was grown in nutrient broth medium at $37^{\circ} \mathrm{C}$ for $24 \mathrm{~h}$. Final bacterial numbers were adjusted to $0.5 \mathrm{Mc}$ Farland Turbidometry. A lawn culture then prepared on Muller-Hinton agar using sterile cotton swabs. Sterile filter paper discs $(6 \mathrm{~mm})$ impregnated with reconstituted extract at the concentration of $500 \mathrm{mg} / \mathrm{ml}$ were placed on the culture plates previously seeded with the $0.5 \mathrm{McFarland}$ and $10^{6} \mathrm{cfu} / \mathrm{ml}$ cultures of bacteria. Paper discs impregnated with $20 \mu \mathrm{l}$ of a solution of $10 \mathrm{mg} / \mathrm{ml}$ of chloramphenicol and streptomycin as standard antimicrobials were used for comparison. Antimicrobial activity was determined by measurement of zone of inhibition around each paper disc. For each extract three replicates were used against each organism.

*Author for correspondence: <abiherbal@gmail.com>. 
Data were subjected to statistical analysis using statistical software package SPSS version 14 (SPSS Inc, Chicago, USA). One way analysis of variance (ANOVA) followed by Duncan multiple range test were employed and the differences between individual means were deemed to be significant at $\mathrm{p}<0.05$.

Vitamin $\mathrm{C}$ content in root, stem, leaves and flowers of $E$. littorale ranged from $0.37-4.42$ $\mathrm{mg} / \mathrm{g} \mathrm{FW}$ (Table 1). The flowers contained more vitamin $\mathrm{C}$ than leaves, stem and root. The vitamin $\mathrm{E}$ content in leaves, stem, root and flowers of E. littorale ranged from 1.51 to $2.66 \mathrm{mg} / \mathrm{g}$ FW (Table 2). The highest vitamin E content was observed in leaves of Moringa oleifera (Sanchez-Machado et al. 2006). The total phenolic content of root, stem, leaves and flowers in the different parts of E. littorale ranged from 4.69 to $7.90 \mathrm{GAE} / \mathrm{g}$ DW and showing the highest amount in flowers (Table 1).

Table 1. Biochemical components in different parts of Enicostemma littorale.

\begin{tabular}{lcccc}
\hline Biochemical components & Leaf & Stem & Root & Flower \\
\hline Vitamin C (mg/g FW) & $4.11 \pm 0.05$ & $3.61 \pm 0.04$ & $0.37 \pm 0.26$ & $4.42 \pm 0.34$ \\
Vitamin E (mg/g FW) & $2.66 \pm 0.07$ & $2.48 \pm 0.02$ & $1.51 \pm 0.05$ & $2.51 \pm 0.11$ \\
Total phenols (GAE/g DW) & $5.59 \pm 0.06$ & $5.89 \pm 0.01$ & $4.69 \pm 0.11$ & $7.90 \pm 0.02$ \\
Protein $(\mathrm{mg} / 100 \mathrm{~g})$ & $6.08 \pm 0.04$ & $6.04 \pm 0.02$ & $5.85 \pm 0.01$ & $4.01 \pm 0.02$ \\
Carbohydrate $(\mathrm{mg} / 100 \mathrm{~g})$ & $10.21 \pm 0.07$ & $9.18 \pm 0.03$ & $8.21 \pm 0.05$ & $6.01 \pm 0.01$ \\
\hline
\end{tabular}

Each value is the mean of three replicates \pm standard deviation.

Table 2. Antibacterial activity of different extracts of Enicostemma littorale using different solvents.

\begin{tabular}{|c|c|c|c|c|c|c|c|c|c|c|c|}
\hline \multirow{3}{*}{ Bacteria } & \multicolumn{11}{|c|}{ Diameter of zone of inhibition (mm) } \\
\hline & \multicolumn{2}{|c|}{$\begin{array}{l}\text { Leaf extract } \\
(500 \mathrm{mg} / \mathrm{ml})\end{array}$} & \multirow[b]{2}{*}{$\mathrm{AC}$} & \multicolumn{3}{|c|}{$\begin{array}{l}\text { Stem extract } \\
(500 \mathrm{mg} / \mathrm{ml})\end{array}$} & \multicolumn{3}{|c|}{$\begin{array}{l}\text { Root extract } \\
(500 \mathrm{mg} / \mathrm{ml})\end{array}$} & \multicolumn{2}{|c|}{ Antibiotic } \\
\hline & $\mathrm{CL}$ & ME & & $\mathrm{CL}$ & ME & $\mathrm{AC}$ & $\mathrm{CL}$ & ME & $\mathrm{AC}$ & $\mathrm{Ch}$ & $\mathrm{St}$ \\
\hline Escherichia coli & 10 & 9 & 8 & 14 & 15 & 10 & 12 & 14 & 9 & 15 & 15 \\
\hline $\begin{array}{l}\text { Klebsiella } \\
\text { pneumoniae }\end{array}$ & 10 & 11 & 11 & 12 & 16 & 11 & 12 & 13 & 13 & 17 & 17 \\
\hline $\begin{array}{l}\text { Pseudomonas } \\
\text { aeruginosa }\end{array}$ & 16 & 14 & 14 & 17 & 17 & 16 & 18 & 16 & 11 & 18 & 17 \\
\hline $\begin{array}{l}\text { Staphylococcus } \\
\text { aureus }\end{array}$ & 11 & 14 & 11 & 12 & 15 & 12 & 9 & 11 & 12 & 4 & 8 \\
\hline Bacillus cereus & 16 & 13 & 16 & 18 & 18 & 17 & 13 & 11 & 10 & 20 & 18 \\
\hline Bacillus subtilis & 18 & 18 & 9 & 20 & 19 & 11 & 18 & 15 & 10 & 22 & 24 \\
\hline
\end{tabular}

CL:Chloroform extract, ME: Methanol extract, AC: Acetone extract, Ch: Chloramphenicol, St: Streptomycin

Among the plant extracts, chloroform extract showed maximum antibacterial activity in comparison to methanol and acetone extracts. Among the leaf, stem and root extracts, the stem extract showed maximum antibacterial activity. The chloroform extract of stem showed the highest activity (about $20 \mathrm{~mm}$ inhibitory zone) against Bacillus subtilis (at $500 \mathrm{mg} / \mathrm{ml}$ ) followed by the methanolic stem extract (Table 2). The chloroform extract of $E$. littorale showed better activity against all the tested bacteria. Results showed that the chloroform extract has higher antibacterial activity than that of methanol and acetone extracts. The stem extracts displayed higher antibacterial activity than the leaf and root extracts. This might be due the maturity of the stem which contain other secondary metabolites and bitter principles of the plant. Earlier results suggested that antimicrobial 
compounds from natural leaf and stem extracts might benefit oral health as plaque-control agents for the prevention of dental caries and periodontal disease (Yim et al. 2010). Antimicrobial assessment of the crude extracts of Gunnera perpensa indicated that the highest sensitivity was obtained from the stem extracts, and the least activity was noted for the root extracts (Drewes et al. 2005).

From the present research it is evident that E. littorale is rich in vitamin $\mathrm{C}$, vitamin $\mathrm{E}$ and it has good antibacterial activity. Therefore, the plant may contribute significantly to the nutrient requirements of human being and may act as antibiotics.

\section{Acknowledgement}

The work was carried out as part of project work under "Innovation in Scientific Pursuit for Inspired Research programme" (INSPIRE), by the Department of Science and Technology, Government of India, awarded to the first author.

\section{References}

Ali SS, Kasoju N, Luthra A, Singh A, Sharanabasava H, Sahu A and Bora, U 2008. Indian medicinal herbs as sources of antioxidants. Food Res. Int. 41: 1-15.

Backer H, Frank O, De Angelalls B and Feingold S 1980. Plasma tocopherol in man at various times after ingesting free or ocetylaned tocopherol. Nutr. Rep. Int. 21:531-536

Bradford MM 1976. A rapid and sensitive method for the quantification of microgram quantities of protein utilizing the principle of protein-dye binding. Anal. Biochem.72: 248 -254.

Brantner A and Grein E 1994. Antibacterial activity of plant extracts used externally in traditional medicine. J. Ethnopharmacol. 44: 35-40.

Drewes SE, Khan F, Sandy F, Van Vuuren SF and Viljoen AM 2005. Simple 1,4-benzoquinones with antibacterial activity from stems and leaves of Gunnera perpensa. Photochemistry 66: 1812-1816.

Dubois M, Giles MK, Hamilton JK, Reber PA and Smith R 1956. Colorimetric methods for determination of sugar and related substances. Anal. Chem. 28: 350-356

Malick CP and Singh MB 1980. Plant enzymology and histo enzymology. Kalyani Publishers. New Delhi. pp. 286.

Murali B, Upadhyaya UM and Goyal RK 2002. Effect of chronic treatment with Enicostemma littorale in non- insulindependent diabetic (NIDDM) rats. J. Ethnopharmacol. 81 : 199-204

Omaye ST, Turnbull JD and Sauberlich HE 1979. Selected methods for the determination of ascorbic acid in animal cells, tissues and fluids. Methods Enzymol. 62: 3-11.

Sanchez-Machado DI, Lopez-Cervantes J and Rios Vazquez NJ 2006. High-performance liquid chromatography method to measure $\alpha$ - and $\gamma$-tocopherol in leaves, flowers and fresh beans from Moringa oleifera. J. Chromatogr. A . 1105: 111-114.

Yim NH, Ha DT, Trung TN, Kim JP, Lee SM, Na MK, Jung HJ, Kim HS, Kim YH and Bae KH 2010. The antimicrobial activity of compounds from the leaf and stem of Vitis amurensis against two oral pathogens. Bioorg. Med. Chem. Lett. 20: 1165-1168.

(Manuscript received on 20 October, 2012; revised on 23 April, 2013) 